\title{
Observations on the behaviour of the scavenging lysianassoid Orchomene zschaui (Crustacea: Amphipoda) from South Georgia (South Atlantic)
}

\author{
P. G. Moore \\ University Marine Biological Station, Millport, Isle of Cumbrae, Scotland KA28 0EG, United Kingdom
}

\begin{abstract}
Orchomene zschaui (Pfeffer, 1888) dominated the catch of scavengers attracted to heads of dead elephant seals suspended above the sea bed at Husvik, South Georgia. No ovigerous female, and few juvenile, amphipods were captured. Activity was nocturnal. No lunar rhythm in catch rate was detected: encounters with bait (by visiting shoals of amphipods?) seemed to be by chance. Habitat choice experiments revealed a kinetic preference for dark vs light places, antipathy towards sand and a consistent choice of alternatives which offered high surface contact. Amphipods survived 4 ppt salinity for $30 \mathrm{~min}$. Temperatures between -2 and $+10^{\circ} \mathrm{C}$ were tolerated, but rapid removal from $+2{ }^{\circ} \mathrm{C}$ to $+12^{\circ} \mathrm{C}$ resulted in heat shock effects. In the field, amphipods nestled into the pelt of the seal head, often near a facial orifice, and began penetration of the epidermis, creating larger and larger holes with time. The stomach of $O$. zschaui occupies $41 \%$ of body length. Analysis of stomach contents showed that consumption of dark epidermal tissue (as strips) only preceded white blubber, i.e. never followed it. The degree of stomach fullness of amphipods captured at night increased progressively through the hours of darkness. The rate at which stomach fullness declined with time depended on the material consumed: 9 to $10 \mathrm{~d}$ for seal epidermis, $2 \mathrm{~d}$ for blubber. Replete amphipods lose some $20 \%$ of total dry weight if starved for $23 \mathrm{~d}$
\end{abstract}

KEY WORDS: Amphipoda $\cdot$ Scavenger $\cdot$ Behaviour $\cdot$ South Georgia

\section{INTRODUCTION}

Lysianassoid amphipods contribute significantly to epibenthic scavenger assemblages in the deep sea and in shallow waters in high latitudes (Slattery \& Oliver 1986). Their foraging behaviour has been studied extensively using baited trapping techniques (see review by Sainte-Marie 1992). Lysianassoids are voracious feeders - their bait-stripping activities from long-lines are legendary (see Templeman 1967 and Vader \& Romppainen 1985) - and their efficiency as scavengers can be judged from the fact that seal flesh which has been protected from amphipods may remain submerged in Antarctic waters almost unchanged for 6 wk (Dayton 1970, author's pers. obs.). In the presence of amphipods carrion was swiftly consumed.

Studies on bait selectivity, the sequence of tissue exploitation of carcasses by lysianassoids, and the extent that these animals might optimize foraging tactics, however, are lacking. Orchomene zschaui (Pfeffer, 1888) is a little known species (originally allocated to Orchomenopsis) which has been recorded from South Georgia and the Antarctic Peninsula (De Broyer 1985). Schellenberg (1931) gave no ecological details pertaining to it apart from noting depths ( 1 to $310 \mathrm{~m}$ ) and bottom type (sand, shingle, algae) of samples yielding the species. In allocating this species to Orchomene, I follow the recent taxonomic scheme of Barnard \& Karaman (1991).

\section{MATERIALS AND METHODS}

Amphipods for experimental work were collected by suspending the severed heads of elephant seal Mirounga leonina pups, which had newly died from 
natural causes, 2 to $3 \mathrm{~m}$ below the sea surface and some $1 \mathrm{~m}$ above the seabed beneath the jetty at Husvik, Cumberland Bay, South Georgia (54 $11^{\prime} \mathrm{S}, 36^{\circ} 40^{\prime} \mathrm{W}$ ). Sea surface temperature in situ was 2 to $3^{\circ} \mathrm{C}$.

Orchomene zschaui was the only scavenging amphipod encountered during the study. In life the species is pale yellowish white with yeliow markings on coxae 5 , 6 and 7 . Eye colour is black. Haemolymph colour is violet. The occasional other amphipods caught (e.g. stenothoids, eusirids) represented species displaced from fronds of the giant kelp Macrocystis pyrifera which grew on the jetty and past which the bait was hauled

The seabed in the vicinity of the Husvik jetty consisted largely of small, flat stones and flaky gravel, the products of erosion of the laminated country rock (see Clapperton 1971), volcaniclastic sandstones and shales of the Cumberland Bay Formation (Headland 1984). Early deployments of traps on the seabed revealed the presence of scavenging starfish and whelks locally. To avoid possible complications arising from interactions with these species (note Presler 1986), bait was always suspended midwater. Under these circumstances Orchomene zschaui was the only consumer

Observations were made on the posture adopted by Orchomene zschaui when resting and swimming. Diurnal patterns of activity were investigated both in the laboratory and in the field.

A large sample $(n=207)$ of Orchomene zschaui were added to an aquarium containing ca $6 \mathrm{l}$ of static seawater and allowed to settle. No food or substratum was supplied. A $5 \times 10 \mathrm{~cm}$ deep panel was drawn on one side of the tank extending from the water level to $2 \mathrm{~cm}$ above the bottom. Amphipod activity was assessed by counting the number of intrusions into, or through, that panel in a 2 min period at hourly intervals for $27 \mathrm{~h}$. Undoubtedly this involved repeat counting of individuals, but this could not be avoided. During the night, observations were made by red-filtered (Cokin no. 23) torchlight. Surveillance of these individuals on an ad hoc basis continued for several weeks following. Reported times are local (GMT - $2.5 \mathrm{~h}$ ).

A complementary study of the activity cycle of Orchomene zschaui in the field was done over a $24 \mathrm{~h}$ period on 18 November 1993. The head from a freshly dead elephant seal pup was suspended of the jetty at 06:45 $\mathrm{h}$ (immersed $2 \mathrm{~m}$ ). Every hour the bait was hauled to the surface and washed off using a standard procedure. The numbers of $O$. zschaui and the stomach fullness index (see below) of amphipods on each occasion sampled were ascertained. The sex ratio of the numerically more productive, pooled night-time samples was determined

In order to investigate possible longer term cycles of activity associated with tidal cycles and/or any change in attractiveness of a seal head as decay proceeded, the head from a freshly dead seal pup was suspended off the jetty and monitored daily for a period of 39 successive days. Each morning at $06: 30$ h the head was hauled to the surface and washed with seawater in the same standard way. This head was repositioned (slightly) on 12 December 1993 to avoid the influence of glacial melt freshwater which flowed into the bay after a few particularly warm days.

To investigate behaviour in relation to inanimate substrata, the following choice experiments were done in the laboratory. Firstly, amphipods were allowed $24 \mathrm{~h}$ after capture to acclimatise to laboratory conditions before experimentation. Thirty individuals, selected at random from stock (sex not determined), were placed in a shallow plastic tray $(26 \times 18 \times 5 \mathrm{~cm})$ containing seawater, situated lengthwise against an east-facing window in an unheated room. To ensure uniformity of illumination, experiments were done on overcast days. Room temperatures varied between 3 and $9^{\circ} \mathrm{C}$. A sequence of choices was set up as follows: (1) both sides empty (control); (2) one side with strips of transparent Perspex; (3) both sides with flat, dark coloured stones from an adjacent storm beach (control); (4) 1 side with dark sand and the other with dark, flat stones (derived from frost shattering of laminated country rock; see Clapperton 1971) from the same beach; (5) 1 side with dark flat stones and the other with an equivalent mass ( $300 \mathrm{~g})$ of dark, round stones of identical composition (greywackes and tuffs). All choice experiments were run for $2 \mathrm{~h}$ and then repeated with tray orientation reversed. Additionally, the behaviour of 10 Orchomene zschaui swimming over a surface completely covered in sand was observed in the laboratory.

To investigate directional reactions to light, 30 acclimated amphipods, selected at random from stock (sex not determined), were placed in the middle of a $25 \times$ $10 \times 10 \mathrm{~cm}$ Perspex choice chamber, one half of which was made opaque with black insulating tape. The box was deployed during daylight in an unheated room (temperature ca $5^{\circ} \mathrm{C}$ ) lit by windows on 2 sides. A $40 \mathrm{~W}$ tungsten lamp shone directly over the middle of the box from $50 \mathrm{~cm}$ above. Replicate trials were done with the chamber in reverse orientation. Reaction of Orchomene zschaui to materials of differing opacity that each offered equivalent surface contact was tested in a shallow tray of seawater (see above), one half of which was covered in pieces of broken, weathered glass selected piece for piece to match in area with dark flat stones presented in the other half of the tray.

Brief observations were also made of the species' tolerance to salinity, as follows: 25 individuals were set up, 5 in each of 5 replicate $250 \mathrm{ml}$ beakers containing $200 \mathrm{ml}$ of each test water of $100 \%, 50 \%, 25 \%, 12.5 \%$ 
or $0 \%$ seawater $\left(\mathrm{SW}_{;} 0 \% \mathrm{SW}\right.$ was distilled water) tested sequentially. Full strength SW had 34 ppt salinity and 1 beaker of $100 \%$ SW was included as a control in every run of a 5 replicate dilution trial. Amphipods collected from the field (sea temperature $2^{\circ} \mathrm{C}$ ) were held at $2^{\circ} \mathrm{C}$ overnight in full strength SW without food, then prewashed in test water prior to adding to test beakers. Experiments were run at $2^{\circ} \mathrm{C}$ in a Haake F3-K glycol bath. The time taken for cessation of activity and inability to respond to mechanical stimulation with a blunt seeker was noted. Responses were noted up to an experimental duration of $30 \mathrm{~min}$. Individuals were returned to full strength SW thereafter (usually overnight) to gauge recovery. Actual salinities were checked using an optical refractometer (Atago Co. Ltd, Japan, accuracy $\pm 0.5 \mathrm{ppt}$.

Temperature tolerance was not assessed critically but notes were kept of temperatures which amphipods in full strength salinity tolerated in the laboratory, and of the behaviour of amphipods which did not.

Stomach length as a percentage of body length (rostrum tip to telson tip) was measured in a sample of dissected specimens. Since individuals captured had all gorged on the bait for variable periods of time, only limited opportunity availed itself for determining the identity of anything consumed prior to the encounter with the experimental seal head. The composition of material in the hindguts of 1 sample (of 26 specimens) collected on 20 November 1993, therefore, was investigated in the hope that it might shed light on the amphipods' previous feeding history.

On different occasions during the study, several observations were made on the rate at which solid material disappeared from the stomach contents of amphipods held without food in aquaria after removal from seal heads immersed for different periods. Stomach fullness was recorded on a 3 point scale (full, some, empty) and notes were maintained as to the colour of solids and/or liquids contained. A stomach fullness index was derived by allocating a factor of $\times 2$ to any individuals in a sample with full stomachs, $\times 1$ to individuals with 'some' and $\times 0$ to individuals with stomachs empty of solids. The summation of all values for individuals in a sample was divided by the number in the sample to furnish the fullness index, which thus varied between 2 and 0 . The deficiencies of this simplistic approach are appreciated fully, e.g. the term 'full' implies only that food was present throughout the length of the stomach and makes no allowance for volumetric differences of distension between individuals, but the method has the advantage of simplicity. Food preferences were inferred from observations on the pattern of food items in the stomach contents (reflecting consumption sequence) and from the condition of different tissues of the bait heads over time.
Weight loss over a 23 d period of starvation was assessed by comparing the dry weight/body length relationship of 10 individuals freshly collected from the field with the same number which had been kept in the laboratory without food for that period of time. Weights were determined after drying to constant weight at $60^{\circ} \mathrm{C}$.

\section{RESULTS}

\section{Population structure}

No ovigerous female, and few juvenile Orchomene zschaui were ever captured.

\section{Posture and activity}

When sitting upright on a solid surface, the ventral flexure of the urosome of Orchomene zschaui was accompanied by a Z-like reflexure posteriorwards of both the rami of the third uropods and of the telson which came to lie along the dorsum (then ventrad) almost reaching the dorsal spike on urosomite 1. Rapid forwards rotation of these structures gave added impetus to the 'tail flip' which propels the animal forwards from rest (see Kaufmann 1994). The dorsal spike on urosomite 1 may also give the animal extra purchase on the substratum (in the manner of a crampon) in this manoeuvre.

In the absence of alternative surfaces for contact, Orchomene zschaui would congregate together forming tight 'balls', which were sufficiently resistant to breakage to be picked up and handled as entities, or rolled around the container with a directed jet of water, at least for a limited period, with amphipods within these aggregations adopting different orientations.

Swimming was generally in a straight line. When first introduced into an illuminated container with water of acceptable temperature and salinity, amphipods initially swam around rapidly, dorsal surface upwards, with uropods 1 and 2 flared laterally as a stabilizing fan. No directional co-ordination was apparent between individuals which swam around haphazardly. Specimens encountering the bottom would often swim along it on their sides prior to taking off again. Downwards as well as upwards movement was by active swimming (cf. below, on heat shock effects). An amphipod encountering a quiescent conspecific on the bottom would often remain in contact with that individual and cease swimming for a short period. Gradually (typically after 1 to $1.5 \mathrm{~h}$ ) swimming activity in the group would cease as more and more individuals encountered 'balls' of inactive amphipods. 


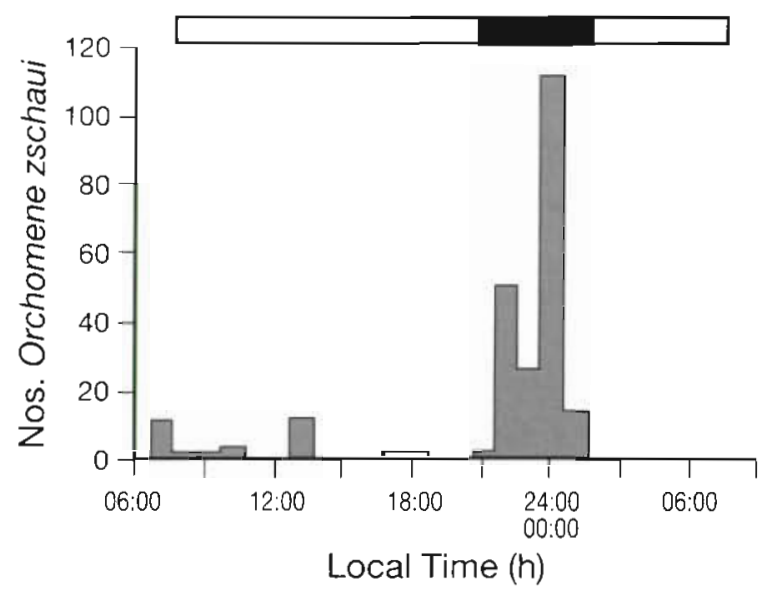

Fig. 1. Orchomene zschaui. Numbers occurring in washings made every hour of the severed head of an elephant seal pup (which had died from natural causes) suspended beneath the Husvik jetty. The bar along the top indicates night ( $\boldsymbol{\square}$ ) and day ( $\square$ )

In the field, amphipods were captured in greatest numbers at night (Fig. 1), although a few were recovered during daytime hauls. The sex ratio (M:F) of specimens recovered during a period of darkness (pooled samples, $\mathrm{n}=151$ ) was $1: 2.08$, a female dominance which was very highly significantly different from unity $\left(\chi^{2}=18.60,1 \mathrm{df}, \mathrm{p}<0.001\right)$. The activity pattern of unfed Orchomene zschaui kept under a natural light/ dark regime in the laboratory was also distinctly nocturnal (Fig. 2), but included a short burst of activity in the early morning. Swimming activity involved most individuals in the tank and was not sexually biassed. An early morning burst of activity was observed consistently in the same batch of individuals which were

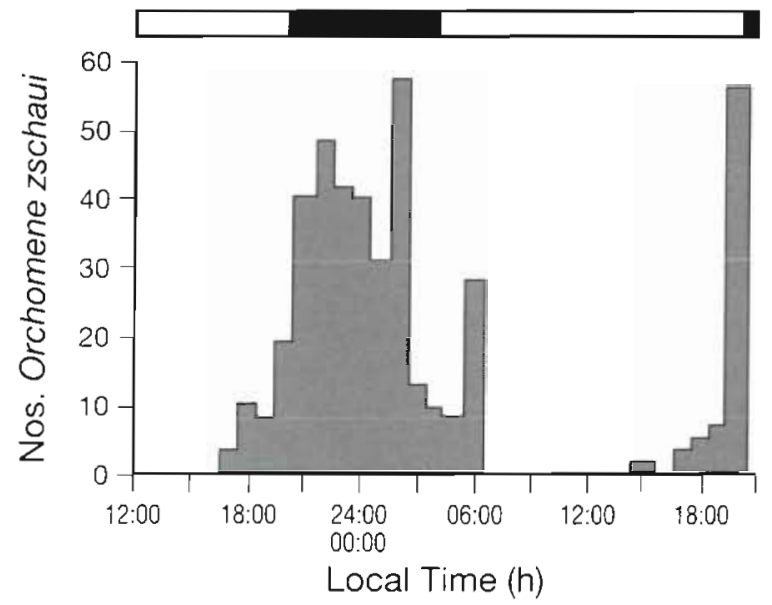

Fig. 2. Orchomene zschaui. Nocturnal swimming activity, as numbers per 2 min passing across a defined field, assessed hourly, in static water in the laboratory (natural illumination). Period of darkness indicated by ( kept for a $23 \mathrm{~d}$ period, and in other batches held in the laboratory in empty containers. That daytime quiescent individuals would resume swimming activity if removed to a dark place suggested that the response to the light/dark cycle was exogenous, rather than endogenous, in origin.

Were a tidal rhythm of activity to characterize Orchomene zschaui, a regular oscillation of numbers captured on a daily basis would be expected. Equally, were the attractiveness of the bait to wax or wane with time one might anticipate finding a trend towards more or fewer individuals with time. Neither of these possibilities is supported by the field data available (Fig. 3), which rather point towards chance encounter as the main operative factor.

Universally, amphipods subjected to an experimental jet of seawater would tuck their heads ventrally between the anterior coxae and remain still, in an upright position, clinging to the substratum. As soon as the water jet stopped, however, they would move away. That this species has a high capacity to cling to substrata when subjected to strong water movement suggests both that few individuals would have been lost from the bait during hauling procedures, and that emergence from benthic shelters might be inhibited on stormy days (see Fig. 3).

\section{Habitat choice}

Under the experimental illumination conditions used, swimming Orchomene zschaui showed no pref-

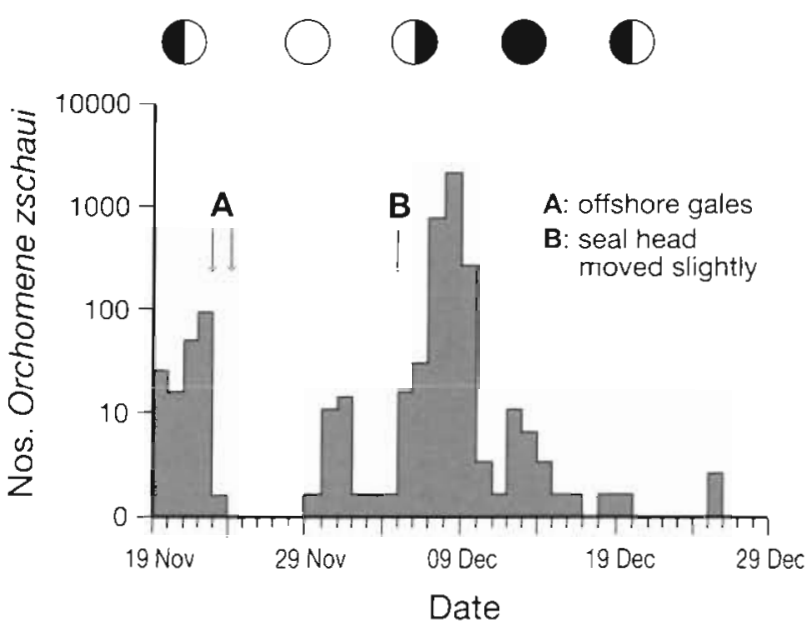

Fig. 3. Orchomene zschaui. Numbers occurring in washings made each day (at 06:30 h) of a seal head. Dates arrowed at (A) indicate a period of strong offshore gales. At (B) the head was moved laterally some $5 \mathrm{~m}$ and lowered by some $2 \mathrm{~m}$ to avoid contact with surface waters of low salinity caused by glacial melt flowing into the bay from a nearby stream. The phases of the lunar cycle are indicated above the histogram 
erence for one end of the control tray compared with the other, either when the tray was empty $\left(\chi^{2}=0.0\right.$ $1 \mathrm{df}, \mathrm{p}>0.05$ ) or when uniformly covered with flat, dark stones $\left(\chi^{2}=0.53,1 \mathrm{df}, \mathrm{p}>0.05\right)$. The choice chamber apparatus was thus without inherent directional cues.

In a choice between lit and shaded conditions, Orchomene zschaui chose the latter $\left(\chi^{2}=35.3,1 \mathrm{df}, \mathrm{p}<\right.$ $0.001)$. Given the choice between the same surface area for contact presented as dark stones (opaque) or broken plate glass (transparent) they chose the former in very significant numbers $\left(\chi^{2}=74.71,1 \mathrm{df}, \mathrm{p}<0.001\right)$.

In a container whose bottom was covered in beach sand from the vicinity of the collection site, amphipods initially (first $90 \mathrm{~min}$ ) swam extensively, but finally came to rest on the sand surface. There they either lay on their sides or, more usually, adopted an upright position clustered together at the edge of the container. No tendency to bury themselves in the sand was discerned. Indeed, given a choice between sand and flat stones, they avoided sand consistently and very significantly $\left(\chi^{2}=60.00,1 \mathrm{df}, \mathrm{p}<0.001\right)$. Significant response to contact with surfaces, however, was revealed: (1) by their clustering around pieces of flat, transparent Perspex when these were laid on the bottom at one end of the dish only $\left(\chi^{2}=26.13,1 \mathrm{df}, \mathrm{p}<\right.$ 0.001 ); (2) by their very significant preference for flat, rather than rounded, stones of the same total mass $\left(\chi^{2}=\right.$ 32.27, $1 \mathrm{df}, \mathrm{p}<0.001$ ); (3) in the clumping behaviour witnessed in the activity investigations (above); and (4) in their behaviour on the bait in situ, where to gain the best purchase and avoid dislodgement, animals typically nestled into the pelt and penetrated the facial orifices of the suspended seal head.

\section{Salinity and temperature tolerance}

In $12.5 \%$ SW (salinity 4 ppt), amphipods were active initially, but swimming reduced gradually in the first 5 min and individuals sank to the bottom of the beakers still beating their pleopods. After $10 \mathrm{~min} 8$ individuals $(32 \%)$ remained capable of responding to mechanical stimulation by swimming. After 30 min no superficially visible signs of activity remained. All specimens, however, recovered when replaced in full strength SW. In $25 \% \mathrm{SW}$ (8 ppt) only 1 individual (4\%) was still beating its pleopods after 30 min compared with all amphipods in $50 \% \mathrm{SW}$ (17 ppt), but all in both groups recovered when returned to $100 \%$ SW. Of 25 amphipods, $21(84 \%)$ failed to respond to mechanical stimulation with a blunt seeker after $10 \mathrm{~min}$ in distilled water. After $15 \mathrm{~min}$ in distilled water, only 1 individual was still beating its pleopods and all were incapable of locomotion. Unfortunately, due to an oversight the recovery, or otherwise, of this batch of specimens was not tested.

Incidental observations suggested a capacity to function normally over the temperature range -2 to $+10^{\circ} \mathrm{C}$. Freshly collected Orchomene zschaui (sea temp. 2 to $3^{\circ} \mathrm{C}$ ) brought straight indoors (room temp. $12^{\circ} \mathrm{C}$ ) exhibited what was interpreted to be effects of heat shock. Random rapid swimming was interrupted by periods of passive sinking to the bottom of the container, with amphipods usually falling through the water on their sides, with the pleon curled ventrally into the space covered by the bases of peraeopods 5 to 7. Once on the bottom they lay on their sides quiescently, making no attempt to explore their surroundings or clump together, their pleopods beating (1st pleopod some, 2nd most, 3rd none) only slowly.

\section{Food and feeding}

The stomach of Orchomene zschaui occupies some $41 \%$ of body length (mean $=40.96 \%, n=6$ ). The only identifiable remains in stomachs of individuals recovered from the seal heads was bait tissue. The hindgut of only 1 out of 26 specimens investigated contained with certainty remains other than bait. That specimen's hindgut contained diatoms and filamentous algae. The hindgut of other individuals ( $\mathrm{n}=3$ ) did contain some muscle tissue. Whether this derived from the bait is uncertain. Unfortunately, the rate of consumption of food could not be addressed, since all attempts to trap unfed individuals, given no direct access to bait, failed. Dissection of stomachs from fed individuals revealed strips of tissue (darkly pigmented skin mostly) of variable lengths, but of widths approximating to the length of the incisor cutting blade (ca $0.22 \mathrm{~mm}$ ). Blubber pieces were more variable in shape.

Specimens showed no immediate interest in feeding in the laboratory during the day when presented with thawed seal meat, blubber or blood odours. As soon as a piece of seal meat was presented directly in front of a tethered female which lacked first antennae, the second antennae moved anteriorly towards the stimulus and were withdrawn when the stimulus was withdrawn. This reaction was noted repeatedly with each of several presentations of the food. If the meat was allowed to come into contact with the anterior peraeopods it was immediately grabbed by the first gnathopods, perhaps for anchorage since no attempt was made to feed on the item so held.

Specimens starved for a week made no directional swimming movements towards a muscle cube of thawed (raw) beef placed in their aquarium during the day, but those individuals which encountered it during random swimming attached themselves to it. It 


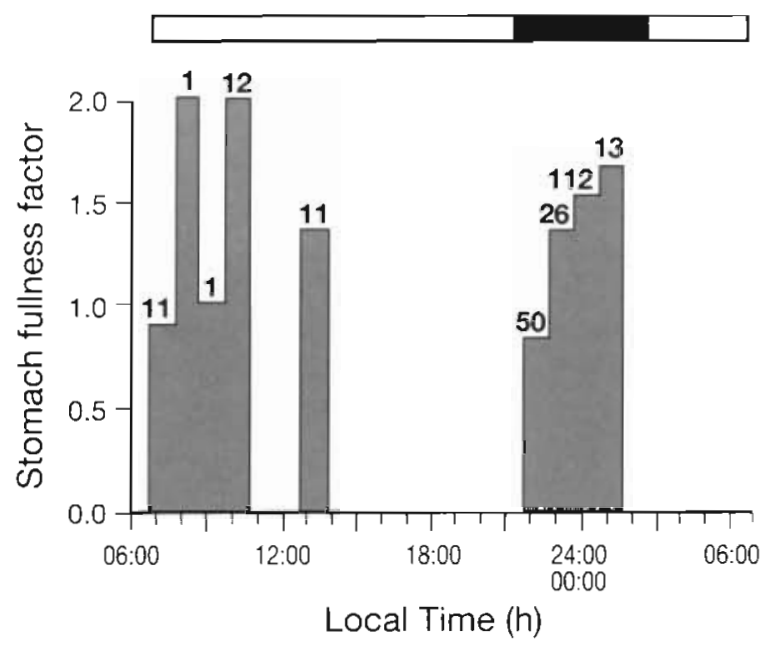

Fig. 4. Orchomene zschaui. Variation in stomach fullness factor, derived from the field samples in Fig. 1. The top bar indicates day $(\square)$ and night ( $\square$ ). Numbers above each bar are $n$ values for each sample

was not possible to see whether feeding commenced immediately. [Note: Kaufmann (1994) noted that Orchomene abyssorum did not begin feeding immediately after reaching a food item, prefacing consumption with a period of 'characterization' of the item.] Severed heads of naturally dead king penguins, i.e. also offering muscle tissue predominantly, which were contemporaneously suspended in the sea near the amphipod productive seal heads (for other purposes) also failed to attract $O$. zschaui. It was clear from observation of the entry points and sequence of exploitation of the seal heads that $O$. zschaui satisfied its requirement for concealment and efficient purchase by nestling into the pelt, ideally near a natural orifice (eye socket, ear opening, vibrissa base) (cf. Heldt 1952), then began to burrow through the skin into the blubber layer at that point. Increasingly large holes were then opened up, around the muzzle of the seal heads especially. Amphipod stomachs contained either dark grey strips of tissue (seal skin) or white blubber, or both. In those stomachs which contained both ( $n=16$ examined) it was consistently the case that the grey skin occupied the posterior of the stomach and the white blubber the anterior rather than the reverse $\left(\chi^{2}=16.00,1 \mathrm{df}, p<0.01\right)$, giving these stomachs a distinctive piebald appearance, i.e. skin was ingested first, then blubber. No example was found of a reverse sequence. No $O$. zschaui were found with red muscle tissue in their stomachs (and only a few with muscle tissue in the hindgut, see above). A large sample of individuals $(n=218)$ collected on 10 December 1993 were categorized as having either grey (skin), or alternatively white solids or yellow orange

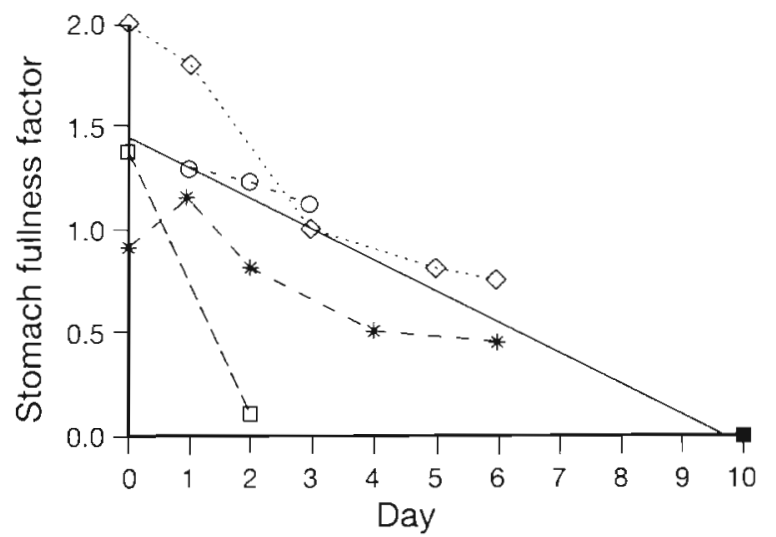

Fig. 5. Orchomene zschaui. Decline with time of the stomach fullness factor, derived from batches of amphipods consuming mainly skin or blubber from bait in the field, then held in the absence of food for varying times under various conditions. First 4 trials relate to consumption of seal skin tissue: $(\diamond \ldots-\diamond)$ 'outdoors' trials, temp. 2 to $5^{\circ} \mathrm{C}_{i}\left(\mathrm{O}_{-}-\mathrm{O}\right)$ laboratory trials, 5 to $9^{\circ} \mathrm{C}$ ( (*- - *) in situ trials, 2 to $3^{\circ} \mathrm{C}_{\text {; }}$ (ロ) starvation experiment (laboratory), 5 to $9^{\circ} \mathrm{C}_{\mathrm{i}}(\square---\square)$ blubber trial (laboratory) 5 to $9^{\circ} \mathrm{C}$. The solid summary line (regression equation: $y=-0.150 x+1.456, R^{2}=0.65,12 d f, p<0.001$ ) represents the general trend in the data for skin tissue. It excludes those for blubber

oil (blubber or blubber breakdown products) in their stomachs. Very significantly more $\left(\chi^{2}=45.87,1 \mathrm{df}, \mathrm{p}<\right.$ $0.001)$ stomachs contained blubber (159) than skin (59). Blubber was thus the dominant food item in this instance. Surprisingly then, given the large cut surface of blubber accessible directly, few $O$. zschaui were observed attached to that (underside) surface when bait heads were hauled up. Conceivably

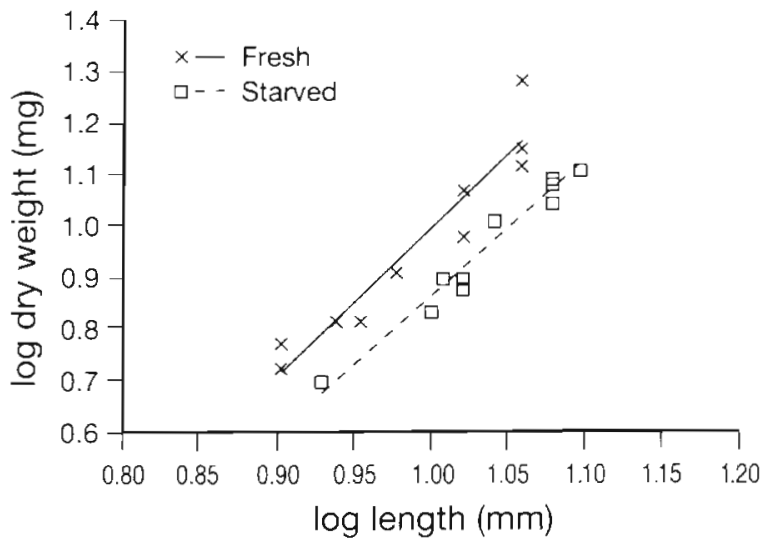

Fig. 6. Orchomene zschaui. Relationship between dry wt (mg) and body length $(\mathrm{mm})$ of amphipods which were either freshly fed or starved for $23 \mathrm{~d}$. Lines are best-fit curves based on least squares linear regression analyses; equations: log dry $w_{t} t_{\text {led }}=2.815(\log$ body length $)-1.825\left(R^{2}=0.91,8 \mathrm{df}\right.$, $p<0.001), \log$ dry $w_{\text {(starved })}=2.629(\log$ body length $)-1.770$ $\left(R^{2}=0.98,8 d f, p<0.001\right)$ 
though, unseen individuals with an insufficient grip could have been more easily dislodged from there. Attrition of blubber inside the skin (circumferentially at the cut section) was certainly noted.

The stomach fullness of specimens captured at night increased progressively during the hours of darkness (Fig. 4) [note: the daytime data relate to so few individuals (see Fig. 1) as to be unreliable]. Fig. 5 shows the data accumulated from various trials on the rate at which stomach fullness (with solids) declines in the absence of food under different temperature conditions, with food of different composition. It is clear that skin tissues take longer to digest ( 9 to 10 d) compared with blubber ( $2 \mathrm{~d}$ ).

Fig. 6 shows the relative weight loss of Orchomene zschaui after a period of $23 \mathrm{~d}$ without food. A $10 \mathrm{~mm}$ standard length individual lost some $20 \%$ of total dry weight over that period.

\section{DISCUSSION}

As an actively swimming shallow-water species, it seems unlikely - on the basis of results reported above - that Orchomene zschaui adopts a 'sit-andwait' strategy involving lengthy periods of burial in superficial sediments (see Smith \& Baldwin 1982), however energy efficient and predation-minimizing such a strategy might be. As Sainte-Marie (1992) pointed out, the probability of detecting a carcass from any one position would be very low. Shallowwater lysianassoids may hide on, or in, the bottom temporarily during the day, emerging at night to search for food (Bregazzi 1972, 1973, Scott \& Croker 1976, SainteMarie 1986, P. G. Moore \& Y. M. Wong unpubl.). The absence of the early morning activity peak in the $24 \mathrm{~h}$ field samples (cf. the laboratory data), however, suggests that in the laboratory this second peak of activity may have been a reflection of the amphipods' frantic attempts to find suitable shelter in an unstructured environment as daylight increased. These experimental amphipods only had one another to cling to in order to satisfy their thigmokinetic requirements.

The only satisfactory explanation both for the inability, encountered from the outset, to trap Orchomene zschaui in baited funnel traps (which have trapped congeners successfully elsewhere; Moore \& Wong unpubl.), and for the intermittency of capture of this species during the long-term field investigation reported above, is that it is not consistently resident in the immediate area sampled. Rather, the view is favoured that $O$. zschaui is a roving scavenger, moving about at night perhaps in loose aggregations until suitable food is encountered. Similarly, Bregazzi (1973) thought that Hippomedon (as Tryphosella) kergueleni might be gregarious to some degree; Hodgson (in Walker 1907) thought that the Antarctic species $O$. plebs 'travels about the sea bottom in vast hordes in search of food'. Kaufmann (1994) has described $O$. abyssorum as having a gregarious nature. Stepien \& Brusca (1985) noted that scavenging amphipod occurrence was more irregular and unpredictable than that of ostracods and isopods. During the daytime it is assumed that $O$. zschaui shelters (possibly gregariously) in dark cover on the seabed, e.g. among stones and shells, in habitats offering high surface contact. Slattery \& Oliver (1986) referred to $O$. plebs and $O$. pinguides 'perching' upon a cobble bottom when not swimming.

The directional avoidance reaction to light appeared to be a kinetic response involving reduction in the level of activity in shaded conditions, rather than a directional taxis. That rhythmic activity in relation to light/dark periodicity in Orchomene zschaui might be exogenously controlled finds support in the observation of Sainte-Marie (1986) that $O$. pinguis remained buried in sediment during the day under clear skies, but that during cloudy weather it emerged from the sediment to swim. Stepien \& Brusca (1985) found no significant effect of the lunar cycle on attacks by crustacean scavengers, although Lampitt et al. (1983) noted that numbers of deep-sea species, including $O$. chevreuxi ( $=0$. cavimanus var.) were related to tidal cycle but not necessarily to periods of low current velocity.

A scarcity or absence of ovigerous or brooding females, or juveniles in hauls of scavenging lysianassoids has been reported by Bregazzi (1972), Slattery \& Oliver (1986) and Sainte-Marie et al. (1990). The nonattraction of such individuals to bait has been related to the need to safeguard vulnerable life history stages (eggs, hatchlings, early stage juveniles) from possible cannibalism during feeding frenzies at carrion (although no consumption of dead conspecifics, feeding frenzy or indeed any inter-individual aggression by Orchomene zschaui was observed in the laboratory). It is possible that holding the bait above the bottom reduced the incidence of smaller animals. It has been reported several times that a size differential exists with swimming 'altitude' in lysianassoids, with smaller individuals not being encountered as far from the bottom as large ones (e.g. Charmasson \& Calmet 1987).

The fact that on seal heads Orchomene zschaui ingested blubber after skin tissue reflects the sequence of carcass penetration. No instance was encountered where an individual must have ingested skin after consuming blubber, i.e. skin consumption is seen only as a necessary preliminary to gaining access to blubber. That most specimens sampled on 10 December 1993 had blubber in their guts reflects the lengthy period of 
immersion (22 d) of the particular seal head from which they were derived. Thus most individuals collected from it by then would have passed the initial penetration phase. Blubber-rich seal heads were productive of $O$ zschaui; however, blubber-poor penguin heads were not

The preferential consumption of carcass lipid resources by vertebrates in polar regions is known for animals as dissimilar as polar bears, which will strip blubber off a ringed seal carcass first, and even leave the remainder (Stirling 1974), and seagulls feeding on stranded pilot whale carcasses (Geraci \& St Aubin 1977). The attraction of blubber reflects both the high energy content of lipids and their ready digestibility (Fig. 5). Rakusa-Suszczewski (1982) inferred a lipid metabolism from respiratory quotient measurements of the Antarctic Orchomene plebs.

An actively swimming scavenger such as Orchomene zschaui would greatly benefit both from the payload efficiency and endurance potential of a lipid fuel and from the improvement in buoyancy which would also result, thereby decreasing the costs of locomotion and conserving energy in an environment with unpredictable refuelling stops. Although clearly an avid consumer of animal tissues, the presence of algal materials in the hindgut of 1 field-collected individual does indicate a preparedness to consume other materials, perhaps when preferred foods are scarce. Scavengers may thus maximize their energetic intake per unit of feeding effort by ingesting the most energy-rich tissues available (Kaufmann 1994).

Sainte-Marie (1992) associated the low catchability of shallow-water lysianassoid genera (including Orchomene) - cf. their deep-sea counterparts - with such characteristics as slower, more wasteful feeding, higher metabolic rates, brief post-feeding phases, more continuous and less efficient feeding. In his opinion, species combining these traits are more likely to be feeding generalists or detritivores. Support for this hypothesis, however, in the present case is equivocal. True, Orchomene spp. retain a triturative molar, and material other than animal carrion has been found in the guts of $O$. zschaui (but only for certain in 1 individual). This species does, however, appear to be quite selective in its feeding behaviour, rejecting opportunities to browse on high protein substrates (seal head muscle and tongue, blubber-poor king penguin heads) in favour of high energy seal blubber. Similar high selectivity of bait characterizes $O$. nanus in Scotland (Moore 1984, Moore \& Wong unpubl.). That freshly ingested stomach contents typically consisted of strips of bait tissue reflects the recent findings of Steele \& Steele (1993) on Anonyx spp. Sainte-Marie (1992) represented members of the genus Anonyx as cleanfeeding, 'batch reactor'-type food processers, but sug- gested that Orchomene spp. were 'plug reactor'-type processers, i.e. untidy shredders. However, the presence of intact strips of food in the stomach contents of O. zschaui suggests that the possession of a triturative molar may not necessarily betoken shredding of food perhaps the molars are used simply to grip food during its passage through the mouthparts.

Surprisingly, no feeding frenzy or frantic searching for food in the presence of food odours (cf. Scott \& Croker 1976, Sainte-Marie 1992) was apparent in the behaviour even of 'starved' Orchomene zschaui in these laboratory experiments. Lysianassoids, however, have been reported as surviving long periods of starvation (Rakusa-Suszczewski 1982), e.g. $60 \mathrm{~d}$ in $O . o b-$ tusa (Christiansen \& Diel-Christiansen 1993), so the present specimens which were starved for 3 wk may not have been especially stressed. Some lipid resources remained visible around the stomach of 'starved' individuals despite apparent weight loss of $20 \%$. The contribution which the weight of a full stomach makes to total body weight in fresh specimens is unknown, so what proportion of the amphipods' own tissue weight is lost during such a period of starvation cannot be estimated. Values in the literature (e.g. Hargrave 1985) suggest that meal weight can represent 30 to $60 \%$ of empty body weight in other lysianassoids. Although when food is plentiful passage through the gut may be quick, when individuals are denied food, they can retain material in the gut for several days 7 to $8 d_{i}$ RakusaSuszczewski 1982; present observations, see Fig. 5). It is thus possible that, to a large extent, the weight loss presently recorded represents meal assimilation (see Fig. 5), not attrition of body tissues.

Comparative data on the environmental tolerances of lysianassoid amphipods are few in number. RakusaSuszczewski (1982) reported the upper lethal temperature for the antarctic Orchomene plebs to be $+8^{\circ} \mathrm{C}$. Busdosh \& Atlas (1975) found that the arctic species Boekosimus (Onisimus) affinis could tolerate abrupt changes in salinity from 30 up to $50 \mathrm{ppt}$ or down to $4 \mathrm{ppt}$, as well as abrupt temperature changes from $5^{\circ} \mathrm{C}$ to $15^{\circ} \mathrm{C}$. Gradual change, however, was tolerated better than abrupt change. It was clear from present observations that $O$. zschaui can tolerate seawater temperatures from freezing to significantly higher than those likely to be encountered in situ in the waters around South Georgia. It is also capable of enduring considerably diluted seawater, at least for the length of time necessary to enable movement away from sources of freshwater in nature. Thus an encounter with superficial water of inappropriate composition (salinity, temperature) in the field, e.g. as a result of meltwater input in shallow bays, would result in active avoidance swimming or downwards passive tumbling (the latter 
of which seems to be the species' shock behaviourj to regain more saline conditions.

The female domination of the only sample analysed is interesting and accords with Rakusa-Suszczewski's findings (1982) on Orchomene plebs. Most other workers, however, have reported lysianassoids as having sex ratios of unity (Ingram \& Hessler 1983, Baldwin \& Smith 1987, Bucklin et al. 1987, Charmasson \& Calmet 1987). The possibility of there being seasonal cycles in sex ratio (Moore 1981), as in species occurrence (Presler 1986), however, cannot be ruled out.

Acknowledgements. The author thanks the British Antarctic Survey for logistic support and for provision of facilities at Husvik. The Royal Society of London and the Transantarctic Association are also thanked for providing grant support for the project. Mr Y. M.Wong kindly computerized the figures. Mr P. Anker-Nilssen is thanked for reassuring me that seal heads would attract amphipods, after all else had failed. I am grateful to Mrs Sheila Anderson for supplying relevant references from the literature on polar vertebrates which were unknown to me.

\section{LITERATURE CITED}

Baldwin, R. J., Smith, K. L. Jr (1987). Temporal variation in catch rate, length, color and sex of the necrophagous amphipod, Eurythenes gryllus, from the central and eastern North Pacific. Deep Sea Res. 34: 425-439

Barnard, J. L., Karaman, G. S. (1991). The families and genera of marine gammaridean Amphipoda (except marine gammaroids). Part 2, Rec. Aust. Mus. Suppl. 13 (part 2): $419-866$

Bregazzi, P. K. (1972). Life cycles and seasonal movements of Cheirimedon femoratus (Pfeffer) and Tryphosella kergueleni (Miers) (Crustacea: Amphipoda). Br. Antarct. Surv. Bull. 30: 1-34

Bregazzi, P. K. (1973). Locomotor activity rhythms in Tryphosella kergueleni (Miers) and Cheirimedon femoratus (Pfeffer) (Crustacea, Amphipoda). Br. Antarct. Surv. Bull. 33/34: 17-32

Bucklin, A., Wilson, R. R. Jr, Smith, K. L. JI (1987). Genetic differentiation of seamount and basin populations of the deep-sea amphipod Eurythenes gryllus. Deep Sea Res. 34: $1795-1810$

Busdosh, M., Atlas, R. M. (1975). Response of two arctic amphipods, Gammarus zaddachi and Boeckosimus (Onisimus) affinis, to variations in temperature and salinity. J. Fish. Res. Bd Can. 32: 2564-2568

Charmasson, S. S., Calmet, D. P. (1987). Distribution of scavenging Lysianassidae amphipods Eurythenes gryllus in the northeast Atlantic: comparison with studies held in the Pacific. Deep Sea Res. 34: 1509-1523

Christiansen, B., Diel-Christiansen, S. (1993). Respiration of lysianassoid amphipods in a subarctic fjord and some implications on their feeding ecology. Sarsia 78: 9-15

Clapperton, C. M. (1971). Geomorphology of the Stromness Bay-Cumberland Bay area, South Georgia. Br. Antarct. Surv. Sci. Rep. no. 70: 1-25

Dayton, P. (1970). Discussion. Benthos (zonation and productivity). In: Holdgate, M. W. (ed.) Antarctic ecology, Vol. 1. Academic Press, London, p. 288

De Broyer, C. (1985). Notes sur les Orchomene de l'Océan
Austral. 3. Révision d'Orchomenella acanthura (Schellenberg) (Crustacea Amphipoda: Lysianassoidea). J. nat. Hist. 19: 729-738

Geraci, J. R., St Aubin, D. J. (1977). Mass stranding of the long-finned pilot whale Globicephala melaena on Sable Island, Nova Scotia. J. Fish. Res. Bd Can. 34: 2196-2199

Hargrave, B. T (1985). Feeding rates of abyssal scavenging amphipods (Eurythenes gryllus) determined in situ by time-lapse photography. Deep Sea Res. 32: 443-450

Headland, R. (1984). The island of South Georgia. Cambridge University Press, Cambridge

Heldt, J.-H. (1952). Note sur quelques petits crustacés ichthyophages. Bull. Soc. Sci. nat. Tunisie 5: 111-113

Ingram, C. L., Hessler, R. R. (1983). Distribution and behavior of scavenging amphipods from the central North Pacific Deep Sea Res. 30: 683-706

Kaufmann, R. S. (1994). Structure and function of chemoreceptors in scavenging lysianassoid amphipods. J. crust. Biol. 14: $54-71$

Lampitt, R. S., Merrett, N. R., Thurston, M. H. (1983). Interrelations of necrophagous amphipods, a fish predator, and tidal currents in the deep sea. Mar. Biol. 74: 73-78

Moore, P. G. (1981). The life histories of the amphipods Lembos websteri Bate and Corophium bonnellii Milne Edwards in kelp holdfasts. J. exp. mar. Biol. Ecol. 49: 1-50

Moore, P. G. (1984). The fauna of the Clyde Sea area. Crustacea: Amphipoda. Univ. Mar. Biol. Stn Millport Occ. Publ. No. 2

Presler, P. (1986). Necrophagous invertebrates of the Admiralty Bay of King George Island (South Shetland Islands, Antarctica). Pol. polar Res. 7(1-2): 25-61

Rakusa-Suszczewski, S. (1982). The biology and metabolism of Orchomene plebs (Hurley 1965) (Amphipoda: Gammaridea) from McMurdo Sound, Ross Sea, Antarctic. Polar Biol. 1: 47-54

Sainte-Marie, B. (1986). Feeding and swimming by lysianassid amphipods in a shallow cold-water bay. Mar. Biol. 91: $219-229$

Sainte-Marie, B. (1992). Foraging of scavenging deep-sea lysianassoid amphipods. In: Rowe, G. T., Pariente, V. (eds.) Deep-sea food chains and the global carbon cycle. Kluwer Academic Publishers, Dordrecht, p. 105-124

Sainte-Marie, B., Lamarche, G., Gagnon, J.-M. (1990). Reproductive bionomics of some shallow-water lysianassoids in the Saint Lawrence estuary, with a review on the fecundity of the Lysianassoidea (Crustacea, Amphipoda). Can. J. Zool. 68: 1639-1644

Schellenberg, A. (1931). Gammariden und Caprelliden des Magellangebietes, Südgeorgiens und der Westantarktis. Further zoological results of the Swedish Antarctic Expedition, 1901-1903, Vol. 2, no. 6, p. 1-290

Scott, K. J., Croker, R. A. (1976). Macroinfauna of northern New England marine sand. III. The ecology of Psammonyx nobilis (Stimpson, 1853) (Crustacea: Amphipoda). Can. J. Zool. 54: 1519-1529

Slattery, P. N., Oliver, J. S. (1986). Scavenging and other feeding habits of lysianassid amphipods (Orchomene spp.) from McMurdo Sound, Antarctica. Polar Biol. 6: 171-177

Smith, K. L. Jr, Baldwin, R. J. (1982). Scavenging deep-sea amphipods: effects of food odor on oxygen consumption and a proposed metabolic strategy. Mar. Biol. 68: 287-298

Steele, D. H., Steele, V. J. (1993\}. Biting mechanism of the amphipod Anonyx (Crustacea: Amphipoda: Lysianassoidea). J. nat. Hist. 27: 851-860

Stepien, C. A., Brusca, R. C. (1985). Nocturnal attacks on nearshore fishes in southern California by crustacean zooplankton. Mar. Ecol. Prog. Ser. 25: 91-105 
Stirling, I. (1974). Midsummer observations on the behaviour of wild polar bears. Can. J. Zool. 52: 1191-1198

Templeman, W. (1967). Predation on living fishes on longline in Baffin Bay by the amphipod Eurythenes gryllus (Lichtenstein), and a new distribution record. J. Fish. Res. Bd Can. 24: 215-217

This article was presented by J. Mauchline, Oban, UK
Vader, W., Romppainen, K. (1985). Notes on Norwegian marine Amphipoda. 10: Scavengers and fish associates. Fauna Norv., Ser. A, 6:3-8

Walker, A. O. (1907). Crustacea III. Amphipoda. National Antarctic Expedition 1901-1904, Natural history, Vol. 3, Zoology and botany, Part 3, p. 1-39

Manuscript first received: March 29, 1994

Revised version accepted: June 16, 1994 